\title{
Functional independence profile of people with physical disabilities
}

\author{
Perfil da independência funcional nas tarefas motoras \\ das pessoas com deficiência física adquirida
}

\section{Perfil de la independencia funcional en las tareas motoras de personas con discapacidad física adquirida}

\author{
Carla Vanessa Cordeiro Rodrigues ${ }^{\circledR}$, Andreia Leffer ${ }^{\circledR}$, Fabíola Hermes Chesani $\oplus^{\oplus}$, Tatiana Mezadri ${ }^{\oplus}$, \\ Leo Lynce Valle de Lacerda $\circledast^{*}$
}

Universidade do Vale do Itajaí (Univali), Itajaí, SC, Brazil

\begin{abstract}
Introduction: The Functional Independence Measure is an evaluation instrument that recognizes the functional evolution of the characteristics of physically disabilities and their abilities. Objective: To analyze the motor items of the functional independence level of people with physical disabilities in the municipality of Itajaí, state of Santa Catarina. Method: A cross-sectional quantitative study was carried out with 164 people with physical disabilities who lived in Itajaí/SC. Socioeconomic variables, and type and cause of disability were collected. To analyze the aspects that limit or contribute to functional independence, the Functional Independence Measure scale was applied. Statistical tests were used for comparisons according to the nature of the variables. Results: Most individuals (39\%) were 41 to 60 years old; $44.5 \%$ had elementary education; only $10.4 \%$ are in the labor market, and $60.4 \%$ earns up to two minimum wages. Regarding
\end{abstract}

* CVCR: BS, email: jk_rodrigues22@hotmail.com AL: BS, email: deialeffer@hotmail.com FHC: PhD, email: fabiola.chesani@univali.br TM: PhD, email: mezadri@univali.br LLVL: PhD, email: leolynce@univali.br 
the type of disability, $58 \%$ of participants presented plegia; $26.2 \%$, paresis; and $15.8 \%$, amputations. The etiology of disability was mainly related to neurological problems (43.3\%). In the distribution of the average score of people with physical disabilities, half of the sample had average scores above six, and $67 \%$ above five, with significant differences in the mean independence scores according to occupation and type of disability. Conclusion: The results obtained support the decision-making process of physical therapists and health professionals.

Keywords: Disability. Physical Therapy. Activity of Daily Living.

\section{Resumo}

Introdução: A Medida de Independência Funcional é um instrumento de avaliação que reconhece as características da evolução funcional dos deficientes físicos. Objetivo: Analisar os itens motores do nível da independência funcional das pessoas com deficiência física adquirida, residentes no município de Itajaí/SC.

Método: Estudo transversal de abordagem quantitativa com 164 pessoas com deficiência física adquirida, residentes na cidade de Itajaí. Foram coletadas variáveis socioeconômicas, tipo e causa da deficiência. Para analisar os aspectos que limitam ou contribuem para a independência funcional, foi aplicada a escala da Medida da Independência Funcional. Foram utilizados testes estatísticos para comparações de acordo com a natureza das variáveis. Resultados: A maioria dos indivíduos (39\%) apresentou de 41 a 60 anos, 44,5\% referiram ensino fundamental, apenas 10,4\% estão inseridos no mercado de trabalho e 60,4\% recebem até 2 salários mínimos. No que se refere ao tipo de deficiência, as plegias estão presentes em 58\% dos participantes, as paresias totalizaram $26,2 \%$ e os amputados foram $15,8 \%$ do total. A etiologia da deficiência foi relacionada principalmente a problemas neurológicos (43,3\%). Na distribuição do escore médio das pessoas com deficiência física percebe-se que a metade da amostra apresentou escores médios acima de seis, e 67\% acima de cinco, com diferenças significativas nas médias dos escores de independência de acordo com a ocupação e tipo de deficiência. Conclusão: Os resultados obtidos fundamentam a tomada de decisão do fisioterapeuta e dos profissionais de saúde

Palavras-chave: Pessoas com Deficiência. Fisioterapia. Atividades Cotidianas.

\section{Resumen}

Introducción: La Medida de Independencia Funcional es un instrumento de evaluación que reconoce las características de la evolución funcional de los discapacitados y sus capacidades. Objetivo: Analizar los ítems motores del nivel de independencia funcional de las personas con discapacidad física adquirida, residentes en el municipio de Itajaí/SC. Método: Estudio transversal de abordaje cuantitativo con 164 personas con discapacidad física adquirida, residentes en la ciudad de Itajaí (Santa Catarina). Se recogieron variables socioeconómicas, tipo y causa de la discapacidad. Para analizar los aspectos que limitan o contribuyen a la independencia funcional, se aplicó la escala de la Medida de la Independencia Funcional. Se utilizaron pruebas estadísticas para comparaciones de acuerdo con la naturaleza de las variables. Resultados: La mayoría de los individuos (39\%) tienen entre 41 y 60 años, el 44,5\% referenció enseñanza fundamental, apenas 10,4\% están insertos en el mercado de trabajo y el 60,4\% recibe hasta 2 salarios mínimos. En lo que se refiere al tipo de discapacidad, las plegias están presentes en el 58\% de los participantes, las parejas totalizaron el 26,2\% y los amputados fueron el 15,8\% del total. La etiología de la deficiencia se relacionó principalmente con problemas neurológicos (43,3\%). En la distribución del puntaje medio de las personas con discapacidad física se percibe que la mitad de la muestra presentó índices medios por encima de seis y un 67\% por encima de cinco, con diferencias significativas en las medias de los índices de independencia de acuerdo con la ocupación y el tipo de discapacidad. Conclusión: Los resultados obtenidos fundamentan la toma de decisión del fisioterapeuta y de los profesionales de salud.

Palabras clave: Personas con Discapacidad. Fisioterapia. Actividades Cotidianas. 


\section{Introduction}

The World Health Organization defines disability as a temporary or permanent loss or abnormality of psychological, physiological, or anatomical structure or function [1]. According to Decree no. 5.296, from December 2,2004, physical disability is characterized by complete/partial and/or temporary/permanent alteration of one or more segments of the human body, causing the impairment of the physical function, presenting itself in the form of paraplegia, paraparesis, monoplegia, monoparesis, tetraplegia, tetraparesis, triplegia, triparesis, hemiplegia, hemiparesis, ostomy, amputation or absence of limb, cerebral palsy, dwarfism, limbs with congenital or acquired deformity, except aesthetic deformities and those that do not produce difficulties in the performance of functions [2].

The 2010 census conducted by the Brazilian Institute of Geography and Statistics (IBGE) shows that $45,623,910$ Brazilians (23.9\% of the population) have some type of disability (visual, auditory, motor, mental, and/or intellectual), and out of them, more than 13 million reported motor disability, which corresponds to $6.95 \%$ of the country's population [3]. The state of Santa Catarina has 1,280,170 people with at least one disability, out of which 289,062 are motor disabilities [4].

To know the aspects that limit or contribute to the functional independence of people with physical disabilities, it is fundamental to evaluate functional capacity, which can be defined as "the individuals' ability to independently perform daily activities or tasks identified as essential for the maintenance of their well-being" [5]. This evaluation can be carried out by different instruments, including the Functional Independence Measurement (FIM).

FIM is a multidisciplinary, accurate, and universal evaluation tool created in 1980 in North America and validated in Brazil in 2000. Reproducibility and reliability tests have shown its ability to measure functional mobility [6]. This scale is widely used with elderly people [7]; people with physical disabilities [8-10]; intensive care unit patients [11]; stroke patients [12]; and children [13].

Considering that physical disabilities represent an important part of the population and can be a considerable obstacle to the performance of daily activities, the measure of the functional independence of these individuals can contribute to the planning of actions and interventions by health professionals and physical therapists for enhancing autonomy and reducing dependence. Therefore, this research aimed to analyze the motor items of the functional independence level of people with physical disabilities in the city of Itajaí/SC.

\section{Method}

This is a quantitative cross-sectional study with people with physical disabilities in the city of Itajaí/SC.

Inclusion criteria were: paraplegia, paraparesis, monoplegia, monoparesis, tetraplegia, tetraparesis, triplegia, triparesis, hemiplegia, hemiparesis, amputation or absence of limb, limbs with acquired deformity, amputation, and amyotrophic lateral sclerosis. Exclusion criteria were: congenital disability, ostomy, mastectomy, dwarfism, and cognitive alterations.

A sample was calculated based on unknown proportions of responses ( $\mathrm{p}=\mathrm{q}=0.05), 95 \%$ confidence level, and 5\% maximum sampling error, resulting in 385 individuals.

Data collection took place in the following places: a) Family Health Strategy (ESF): people with physical disabilities were identified and interviewed in their homes. The teams are located in 22 Basic Health Units (UBS), with 49 teams of ESF (physician, nurse, nursing technicians, and community health agents) covering more than $70 \%$ of the general population; b) Rehabilitation Specialist Center II (CER II): subjects were interviewed on site at days and times previously scheduled; c) Support networks - Foz de Itajaí Association of Physically Disabled People (ADEFI) and Association of Parents and Friends of Disabled People (APAE): people were interviewed at the headquarters of these associations. The surveys were conducted by previously trained researchers from the Nutrition and Physical Therapy Courses of the University of Vale do Itajaí, from July 2015 to February 2016.

To characterize the participants of the study, socioeconomic variables were collected, such as age, schooling, occupation, family income, comorbidities, housing, and type and cause of disability.

The Functional Independence Measure (FIM) consists of an instrument that evaluates 18 categories grouped into six dimensions: 1 - Self-care (feeding, personal hygiene, bathing, dressing upper half, dressing lower half, use of toilet); 2 - Sphincter controls (control of diuresis and defecation); 3 Transfers (bed, chair, wheelchair, toilet, bathroom, 
shower); 4 - Locomotion (walking, wheelchair, stairs); 5 - Communication (understanding, expression); 6 - Social cognition (social interaction, problem solving, memory) [14]. Each item can be classified in a scale of degrees of dependency ranging from 1 to 7 levels, thus classified: 7 = complete independence, corresponding to normality in performing tasks independently; $6=$ modified independence; 5 = supervision, encouragement, or preparation; $4=$ minimum assistance (individual accomplishes $\geq$ $75 \%$ of the task); $3=$ moderate assistance (individual accomplishes $\geq 50 \%$ of the task); $2=$ maximum assistance (individual accomplishes $\geq 25 \%$ of the task); 1 = total assistance (individual accomplishes $\geq$ $0 \%$ of the task). In this study, as well as Costa's [15], FIM was exclusively used with motor items, thus dispensing the communication and cognition part.

Comparisons of the mean values of independence were made and the most appropriate technique was applied according to the number of levels presented for each profile variable (considered as independent variable or categorical factor): for two-level factors (absence or presence of comorbidity), Student t-test was used for independent samples; for factors with more than two levels, analysis of variance (ANOVA) was used, followed by Tukey's test, when necessary. These analyzes allowed us to identify possible relationships between the different measures of independence and their differences according to the profile of people with disabilities. Despite the ordinal nature of the scores, the sample number was high enough for the data to be normal, thus we chose parametric tests at a 5\% significance level. Statistica v.10 was used in all analyzes and graphical representations of the results [16].

This research was approved by the Research Ethics Committee under protocol no. 694.257 and funded by the Foundation for Support of Scientific and Technological Research of the State of Santa Catarina (Fapesc) in the public call Fapesc no. 01/2014 - Universal Program.

\section{Results}

The final sample consisted of 164 individuals with a sampling error of $7.6 \%$. Regarding age, $6.0 \%$ were up to 20 years old; $3.00 \%$ were between 21 and 40 years old; $39.0 \%$, between 41 and 60 years old; and $37.0 \%$, over 60 years old; minimum and maximum ages were 11 and 93 years old. Concerning schooling, 10.3\% of the interviewees were illiterate; $44.5 \%$ reported complete or incomplete elementary education, $33.6 \%$, complete or incomplete high school; and $11.6 \%$, complete or incomplete higher education.

Only $10.4 \%$ of these individuals are included in the labor market with paid employment. The remaining are retired (28.0\%); engaged in household activities (25.6\%); receive disability benefits $(24.4 \%)$; and unemployed (11.6\%). As monthly income, most (60.4\%) receive up to two minimum wages; $30.5 \%$, between two and four minimum wages; and $9.1 \%$, above four.

Regarding the type of disability, $58.0 \%$ of participants presented plegia, with higher frequency of hemiplegia (29.3\%), followed by paraplegias (24.4\%) and tetraplegia (4.3\%). Paresis represented $26.2 \%$ of the sample and amputation, $15.8 \%$. The etiology of the disability was related to neurological problems (43.3\%), traumas (37.2\%), infections (11.6\%), and other causes (7.9\%).

The results of the Functional Independence Measure (FIM) showed scores ranging from five to six for most measures except: feeding (6.1), floor/ wheelchair locomotion (4.8), and stair locomotion (4.2) (Table 1).

Table 1 - Mean, standard deviation, and confidence interval (95\%) of the measures of functional independence of 164 people with physical disabilities from the municipality of Itajaí, in 2015

\begin{tabular}{lccc}
\hline Measure & Mean & $\begin{array}{c}\text { Standard } \\
\text { Deviation }\end{array}$ & $\begin{array}{c}\text { 95\% Confidence } \\
\text { Interval }\end{array}$ \\
\hline Feed & 6.1 & 1.5 & $5.9-6.4$ \\
SC & 5.6 & 1.9 & $5.3-5.9$ \\
Bath & 5.4 & 2.0 & $5.1-5.7$ \\
DUH & 5.4 & 2.0 & $5.1-5.7$ \\
DLH & 5.3 & 2.1 & $5.0-5.6$ \\
Hyg & 5.4 & 2.1 & $5.1-5.8$ \\
BC & 5.5 & 2.4 & $5.1-5.8$ \\
IC & 5.5 & 2.3 & $5.1-5.8$ \\
BT & 5.4 & 2.0 & $5.1-5.7$ \\
TT & 5.3 & 2.1 & $5.0-5.6$ \\
ST & 5.4 & 2.1 & $5.1-5.7$ \\
FL & 4.8 & 2.1 & $4.5-5.2$ \\
SL & 4.2 & 2.4 & $3.8-4.5$ \\
Mean Score & 5.3 & 1.8 & $5.1-5.6$
\end{tabular}

Note: Feed: feeding; SC: self-care; Bath: bathing; DUH: dressing upper half; DLH: dressing lower half; Hyg: intimate hygiene; BC: bladder control; IC: intestinal control; BT: bed/chair/wheelchair transfer; TfbTT: toilet transfer; ST: shower/bathtub transfer; FL: floor/wheelchair locomotion; SL: stair locomotion. 
In the distribution of the mean score of people with physical disabilities, almost half of the sample presented results above six, and $67 \%$ above five, which, according to the FIM Scale, corresponds respectively to supervision, encouragement, or preparation and modified independence.

When the differences in the mean score were observed according to the variables of the socioeconomic profile and type and cause of disability (Table 2), significant differences were found for current occupation (test power: 0.9937) and type of disability (test power: 0.9919). Regarding occupation, those who received disability and household benefits showed a significantly lower independence score (4.7 and 5.0, respectively) than those unemployed (6.3). The other occupations (retired and wage receivers) had intermediate scores and were considered equal to these two extremes. When comparing the scores between the types of disability, the mean independence score of the respondents with plegia (5.0) was significantly lower than those with amputation (6.3). Those who presented paresis showed an intermediate score (5.4) and not significantly different from the others. Subjects who live alone tended to have a higher independence score (5.9) than those who lived with their children (4.7), although this difference did not show any significance.

Table 2 - Mean and confidence intervals of the functional independence mean score according to the socioeconomic characteristics and type and cause of disability of people living in the city of Itajaí, in 2015

\begin{tabular}{llll}
\hline Socioeconomic variables, & \multicolumn{4}{l}{ Mean score of independence } \\
\cline { 2 - 5 } type and cause of disability & MD (95\%Cl) & $\mathbf{N}$ & p-value \\
\hline Age group* & & & \\
Up to 20 years & $5.6(4.4-6.9)$ & 10 & \\
21 to 40 years & $4.9(4.1-5.7)$ & 30 & 0.1995 \\
41 to 60 years & $5.7(5.2-6.1)$ & 64 & \\
Over 60 years & $5.2(4.7-5.6)$ & 60 & \\
\hline Schooling* & & & \\
$\quad$ Illiterate & $4.7(3.6-5.9)$ & 15 & \\
Elementary School & $5.4(5.0-5.8)$ & 65 & 0.5996 \\
High School & $5.3(4.8-5.7)$ & 49 & \\
Higher education & $5.3(4.4-6.1)$ & 17 & \\
\hline Housing* & & & \\
Family & $5.4(5.1-5.7)$ & 126 & \\
Parents & $5.0(3.9-6.1)$ & 15 & 0.3787 \\
Alone & $5.9(4.9-6.7)$ & 10 & \\
Children & $4.7(3.4-6.0)$ & 13 & \\
\hline & & \multicolumn{3}{c}{ (To be continued) }
\end{tabular}

Table 2 - Mean and confidence intervals of the functional independence mean score according to the socioeconomic characteristics and type and cause of disability of people living in the city of Itajaí, in 2015

\begin{tabular}{llll}
\hline Socioeconomic variables, & \multicolumn{3}{l}{ Mean score of independence } \\
\cline { 2 - 4 } type and cause of disability & MD $(95 \% \mathrm{Cl})$ & $\mathbf{N}$ & $\mathbf{p}$-value \\
\hline Occupation* & & & \\
Disability benefit & $4.7^{\mathrm{a}}(4.1-5.4)$ & 40 & \\
Housewife & $5.0^{\mathrm{a}}(4.4-5.6)$ & 42 & \\
Retired & $5.5^{\mathrm{ab}}(5.0-6.0)$ & 46 & 0.0076 \\
Wage earner & $5.9^{\mathrm{ab}}(5.0-6.7)$ & 17 & \\
Unemployed & $6.3^{\mathrm{b}}(5.8-6.7)$ & 19 & \\
\hline Type of disability* & & & \\
Plegia & $5.0^{\mathrm{a}}(4.7-5.4)$ & 95 & \\
Paresis & $5.4^{\mathrm{ab}}(4.8-6.0)$ & 43 & 0.0055 \\
Amputation & $6.3^{\mathrm{b}}(5.9-6.7)$ & 26 & \\
\hline Cause* & & & \\
$\quad$ Neurological & $5.0(4.5-5.4)$ & 71 & \\
Traumatic & $5.7(5.2-6.1)$ & 61 & 0.1689 \\
Infectious & $5.5(4.6-6.4)$ & 19 & \\
Other & $5.4(4.3-6.6)$ & 13 & \\
\hline Comorbidity** & & & \\
No & $5.4(5.1-5.8)$ & 101 & 0.4097 \\
Yes & $5.2(4.7-5.7)$ & 61 & \\
\hline Income* & & & \\
Up to 2 MW & $5.4(5.0-5.7)$ & 99 & \\
$>$ 2 to 4 MW & $5.4(4.9-5.9)$ & 50 & 0.5843 \\
$>4$ MW & $4.9(3.8-5.9)$ & 15 & \\
\hline
\end{tabular}

Note: *One-way ANOVA at $5 \%$ significance level. Letters superscript after means denote equal means in Tukey's posterior test. ${ }^{*}$ Student's t test at $5 \%$ significance level. Variable "schooling" without information for 18 individuals, $n=146$.

\section{Discussion}

Most people with physical disabilities were aged between 40 and 80 years old in this study.

When analyzing the socioeconomic conditions of the individuals sampled, it was observed that only $10.4 \%$ of the interviewees had paid employment. Nogueira [17] and Cordeiro [18] describe how important it is to seek public policies that promote the participation and inclusion of people with disabilities in the labor market, since working plays an essential role of personal fulfillment and social interaction in the lives of these people, and promotes a sense of pertinence, capacity, identity, and autonomy. Almeida [19] correlates low schooling with inclusion in the labor market and emphasizes that education is one of the key factors for inclusion. 
Regarding housing, it was observed that more than $70 \%$ of participants live with their family and that this support prevailed because of proximity to the subject, which, besides providing beneficial effects to the health of the person with disability, reduces feelings of loneliness and stress and contributes to elevating the "meaning of life" and personal control, positively influencing the sensation of physical and psychological well-being [20,21].

Concerning the type of physical disability, it was observed that more than half of the sample had hemiplegia or paraplegia. It is known that these motor changes lead to an asymmetrical postural position, such as a decrease in the weight distribution of the affected or contralateral side, with consequent impairment in dressing, feeding, sitting, and walking [22].

In this research, neurological and traumatic problems were the most present etiologies. The neurological cause may be related to a high incidence of stroke, which, according to the World Health Organization, currently affects 15 million people worldwide. Out of these, 6.2 million die and another five million have some type of disability $[23,24]$. In Brazil, stroke is the leading cause of death in the adult population and one of the main reasons for disability, since $70 \%$ of patients do not return to a productive life. Advances in technologies have increased stroke survival, resulting in a growing increase in the number of people with sensory and motor impairment [25]. Traumatic etiology is associated with traffic and work accidents, atherosclerotic diseases, and diabetes mellitus (DM), which are the main causes of amputation [26].

Results from the FIM scale showed that almost half of the sample had average scores above six, and $67 \%$ above five, indicating that people with physical disabilities tend to be more functionally independent, since, according to the classification of this scale, these scores correspond respectively to supervision, encouragement, or preparation and modified independence.

Significance was obtained in the difference of motor functional independence in two variables: occupation and type of disability. Beneficiaries showed less difference than those unemployed. It is believed that the cause is the fact that beneficiaries are older than those unemployed. Therefore, the older age group may be related to a longer time of motor changes, and thus they try to be more independent in their activities. In the study by Valença et al. [27], the perception of some elderly people about the physical disability is that it brought functional limitation or incapacity to perform several of their activities of daily life, such as personal hygiene, dressing, feeding, and getting around. However, some elderly people assumed the identity of being physically handicapped, showing a way of thinking and acting of adaptation and overcoming.

In this research, amputees are more independent than people with plegia and paresis. For Valença et al. [27], the use of the prostheses is seen on the expectations of the elderly as a way of acquiring greater functional independence and ensuring the maintenance of their social role. Amputation brings more alteration in the daily life, with more limitations and new experiences. These people perceive themselves with a new possibility, of being-diabetic with amputations, having to adjust and live with all this information and obligations [27].

Contrary to the results of this study, Benvegnu et al. [28], when assessing the functional independence measure of individuals with stroke sequelae, observed that those with sequelae were not able to perform simple day-to-day activities, requiring minimal assistance from a caregiver. However, they realized that individuals could present a better FIM score because the tasks were performed by the caregiver to minimize the time of accomplishment by these patients, which ended up not stimulating the improvement of their functional independence [28].

The results of the studies by Aydin [25], Assis [6], and Silva [29] corroborated this research. Where, when analyzing people with physical disabilities acquired through the MIF scale, they had the same results.

Factors that contribute to the functional independence of people with physical disabilities have been the guideline for several studies and research and should be seen in a broad perspective as a result of interdisciplinary work promoting healthy lifestyles [30].

The limitations of the study include the difficulties in obtaining data and the location of people with physical disabilities in health centers and in associations, sometimes because of lack of information or lack of support from the teams, not allowing the previously calculated sample number; as well as the non-application of cognitive test to identify the participants' ability to respond. 


\section{Conclusion}

This study allowed us to analyze the motor items of the functional independence level of people with physical disabilities in the city of Itajaí/SC. The results indicated that people with physical disabilities are more independent in self-care, bathing, dressing upper half, dressing lower half, intimate hygiene, bladder control, intestinal control, bed/chair/wheelchair transfer, toilet transfer, and shower/bathtub transfer; and more dependent on feeding, floor/wheelchair locomotion, and stair locomotion.

The level of functional independence of people with acquired physical disabilities is an excellent field of action for the physical therapist. It is believed that the results obtained support the decisionmaking process of physical therapists and health professionals, both in practice guidelines that reduce the demand for care and the need for help from caregivers to carry out everyday activities and in a practice focused on physical and leisure activities and social and economic participation.

These measures can help minimizing the impact of disabilities and morbidities on the quality of life of people with disabilities. It is important that health services prioritize actions aimed at reducing their influence on the daily life and on the autonomy of these people.

\section{References}

1. Organização Mundial da Saúde. Relatório mundial sobre a deficiência. São Paulo: SEDPcD; 2011.

2. Brasil. Decreto $n^{\circ}$ 5.296, de 2 de dezembro de 2004 . Regulamenta as Leis $\mathrm{n}^{\circ} 10.048$, de 8 de novembro de 2000 , que dá prioridade de atendimento às pessoas que especifica, e 10.098, de 19 de dezembro de 2000, que estabelece normas gerais e critérios básicos para a promoção da acessibilidade das pessoas portadoras de deficiência ou com mobilidade reduzida, e dá outras providências. Diário Oficial, Brasília, DF, 2004, Dec 2.

3. Instituto Brasileiro de Geografia e Estatística. Censo Demográfico 2010. Brasília, DF: IBGE; 2012.

4. Brasil. Plano Nacional dos Direitos da Pessoa com Deficiência. Brasília, DF: Secretaria de Direitos Humanos; 2011.
5. Moraes EN. Princípios básicos de geriatria e gerontologia. Belo Horizonte: CoopMed; 2008.

6. Assis CS, Batista LC, Wolosker N, Zerati AE, Silva RCG. Medida de independência funcional em pacientes com claudicação intermitente. Rev Esc Enferm USP. 2015;5(49):756-61.

7. Santos EB, Rodrigues RAP, Pontes-Neto OM. Prevalence and predictors of post stroke depression among elderly stroke survivors. Arq Neuropsiquiatr. 2016;74(8):621-5.

8. Boaventura LC, Borges HC, Ozaki AH. Avaliação da sobrecarga do cuidador de pacientes neurológicos cadeirantes adultos. Cienc Saude Colet. 2016;21(10):3193-202.

9. Norlin Bagge E, Esbjörnsson E, Sunnerhagen KS. Cognitive screening and behavioural observation of functional ability in patients with multiple episode schizophrenia: an exploratory study. BMJ Open. 2017;7(6):e014783.

10. McCunniff PT, Raey JS, Scott ML, Roach MJ, Moore T, Vallier HA, et al. Operative versus nonoperative management of civilian gunshot wounds to the spinal cord: novel use of the functional independence measure for validated outcomes. World Neurosurg. 2017;106:240-6.

11. Méan M, Bula C, Waeber G. Can mobilization preserve the elderly hospitalized from functional decline? Rev Med Suisse. 2017;13(547):279-81.

12. Ezeugwu VE, Manns PJ. Sleep duration, sedentary behavior, physical activity, and quality of life after inpatient stroke rehabilitation. J Stroke Cerebrovasc Dis. 2017;26(9):2004-12.

13. Marsico P, Mitteregger E, Balzer J, van Hedel HJA. The Trunk Control Measurement Scale: reliability and discriminative validity in children and young people with neuromotor disorders. Dev Med Child Neurol. 2017;59(7):706-12.

14. Hoepers NJ, Oliveira ACC, Schwalm MT, Soratto MT, Ceretta LB. Medidas de independência funcional em uma instituição de longa permanência de idosos. Estud Interdiscipl Envelhec. 2013;18(1):7-26. 
15. Costa FA, Silva DLA, Rocha VM. Severidade clínica e funcionalidade de pacientes hemiplégicos pósAVC agudo atendidos nos serviços públicos de fisioterapia de Natal (RN). Cienc Saude Colet. 2011;16(Suppl. 1):1341-8.

16. Statsoft Inc. Statistica (data analysis software system), Version 10. Tulsa, OK: Statsoft Inc; 2011.

17. Nogueira GC. Perfil epidemiológico da pessoa com deficiência física residente em Florianópolis [dissertation]. Florianópolis: Universidade Federal de Santa Catarina; 2014.

18. Cordeiro AM, Oliveira GM, Rentería JM, Guimarães CA, Grupo de Estudo de Revisão Sistemática do Rio de Janeiro. Revisão sistemática: uma revisão narrativa. Rev Col Bras Cir. 2007;34(6):428-31.

19. Almeida LC. As desigualdades e o trabalho das escolas: problematizando a relação entre desempenho e localização socioespacial. Rev Bras Educ. 2017;22(69):361-84.

20. Machado FN, Machado NA, Soares SM. Comparação entre a capacidade e desempenho: um estudo sobre a funcionalidade de idosos dependentes. Rev LatinoAm Enfermagem. 2013;21(6):1321-9.

21. Santos TR, Alves FP, França ISX, Coutinho BG, Júnior WRS. Políticas públicas direcionadas às pessoas com deficiência: uma reflexão crítica. Rev Agora. 2012;15:210-9.

22. Fagundes JS, Binda AC, Faria JG, Peres D, Michaelsen SM. Instrumentos de avaliação sensorial pós-acidente vascular encefálico (AVE) descritos em português: uma revisão sistemática. Fisioter Pesqui. 2015;22(4):435-42.

23. Nogueira GC. Perfil epidemiológico da pessoa com deficiência física residente em Florianópolis [dissertation]. Florianópolis: Universidade Federal de Santa Catarina; 2014.
24. Luvizutto GJ, Gameiro MO0, Schelp AO, Braga GP, Ribeiro PW, Bazan R. Characterization of patients treated by rehabilitation service after establishing of an acute stroke unit in a Brazilian hospital. J Phys Ther Sci. 2015;27(8):2533-6.

25. Aydin T, Taspinar 0, Kepekci M, Keskin Y, Erten B, Gunel M. Functional independence measure scores of patients with hemiplegia followed up at home and in university hospitals. J Phys Ther Sci. 2016;28(2):553-7.

26. Schoeller SD, Silva DGV, Vargas MAO, Borges AMF, Pires DEP, Bonetti A. Características das pessoas amputadas atendidas em um centro de reabilitação. Rev Enferm UFPE On Line. 2013;7(2):445-51.

27. Valença TDC, Lima PV, Chaves RN, Santana S, Reis LA. Repercussões sociais da aquisição de uma deficiência física na vida de idosos. Rev Kairos. 2017;20(1):41-55.

28. Benvegnu AB, Gomes LA, Souza CT, Cuadros TAB, Pavão LW, Ávila SN. Avaliação da medida de independência funcional de indivíduos com sequelas de acidente vascular encefálico (AVE). Cienc Saude. 2008;1(2):71-7.

29. Silva GA, Dornelles SS, Lima GF, Figueiredo CZM, Paula SEMJ. Avaliação funcional de pessoas com lesão medular: utilização da escala de independência funcional. Texto Contexto Enferm. 2012;21(4):929-36.

30. Ferreira OGL, Carneiro MS, Gusmão CSM, Oliveira SA, Paredes MMAS. Envelhecimento ativo e sua relação com a independência funcional. Texto Contexto Enferm. 2012;21(3):513-8.

Received in $07 / 17 / 2017$

Recebido em 17/07/2017

Recibido en $17 / 07 / 2017$

Approved in 02/26/2019

Aprovado em 26/02/2019

Aprobado en 26/02/2019 